\title{
GLOBAL, ECONOMIC AND TECHNOLOGICAL TRENDS IN HUMAN RESOURCE MANAGEMENT DEVELOPMENT
}

\author{
Zurab Mushkudiani ${ }^{1}$, Badri Gechbaia ${ }^{2}$, Iza Gigauri ${ }^{3}$, Ekaterine Gulua ${ }^{4}$ \\ ${ }^{I}$ Navigation Teaching University, Batumi, Georgia \\ ${ }^{2}$ Batumi Shota Rustaveli State University, Batumi, Georgia \\ ${ }^{3}$ St. Andres Georgian University, Tbilisi, Georgia \\ ${ }^{4}$ Ivane Javakhishvili Tbilisi State University, Tbilisi, Georgia \\ e-mails: ${ }^{1}$ z.mushkudiani@bntu.edu.ge, ${ }^{2}$ gechbaia.badri@bsu.edu.ge, ${ }^{3}$ i.gigauri@sangu.edu.ge, \\ ekaterine.gulua@tsu.ge
}

Received: 08 March 2020; Accepted: 18 April 2020; Published: 26 May 2020

\begin{abstract}
Background: A manager is the one who is responsible for accomplishing the tasks of the organization and who directs the efforts of the organization's employees for this purpose. In this paper, we will focus on one of the functions of management - the function of personnel management and on some trends that the 21st century has brought.

Objectives: of this paper is to explore and identify innovative ways and trends, global, economic and technological shifts in human resource management.

Methods/approach.: We have studied the experience that exists for effective and innovative use of freelancers, social networks and internet applications. We brought them in contact with a number of macroeconomic agents and set out directions and outlines for further research.

Results: In close collaboration with line managers, HR managers have been helping employers to find, hire, dismiss, administer and evaluate employees. However, there are trends in personnel management that substantially change perceptions of how well employers are coping with their HR tasks.

Conclusion: HR department's style and methods are constantly changing. Because of this, many employers are reexamining the organization of their HR functions. These types of HR centres carry out their activities through intranets (centralized networks) or centralized call centres;

Feedback, jokes, and game-specific targeting coincide with many new training apps, and websites such as Knack, Gild, and True Office allow an employer to incorporate game features in training, performance evaluation and recruitment.).
\end{abstract}

Keywords: HR management, Line manager, performance evaluation, technological \& economical trends

JEL classification: D21, M12, M54

\section{How to Cite:}

Mushkudiani, Z., Gechbaia, B., Gigauri, I., Gulua, E. 2020. Global, economic and technological trends in human resource management development. Access journal, ACCESS Press, 1(1): 53-60. DOI:

https://doi.org/10.46656/access.2020.1.1(4)

\section{INTRODUCTION}

A manager is the one who is responsible for accomplishing the tasks of the organization and who directs the efforts of the organization's employees for this purpose. According to most authors, management involves the implementation of five key functions. These include planning, organization, staffing, leadership and control. 
In this paper we will focus on one of the functions of management - the function of personnel management and the trends brought about by the 21 st century.

Human Resource Management (HRM) is the process of hiring, training, evaluating and compensating employees. It takes care of employees' business relationships, health, safety and justice.

Goals and objectives of the study: Increasing the usefulness and effectiveness is very important. It can guarantee that we can get results with the help of people. We can do everything right as a manager - build a brilliant strategy, craft a clear organizational plan, bring up-to-date technologies, and use sophisticated accounting controls - but all of this would be futile if we hired the wrong people or failed to motivate subordinates. On the other hand, many managers, starting with generals and ending with presidents, have succeeded without adequate plans, organizational charts and controls. They were still successful because of their ability to choose the right people for the job. The purpose of this work is to explore and identify innovative ways and trends, global, economic and technological shifts in human resource management.

Originality of the research - We have explored the experience of using freelancers' phenomenon, social networks and internet applications efficiently and innovatively. We brought them in contact with a number of macroeconomic agents. We have set out directions and outlines for further research.

The work consists of three parts:

- Chapter 1. Global trends,

- Chapter 2. Economic Trends.

- $\quad 2.1$ Workforce trends

- Chapter 3. Technological trends.

Economic Trends. Although globalization has supported a growing global economy, serious difficulties have been identified in the world economy over the past 10 years. As shown in Figure 1. Gross domestic product (GDP) of the United States increased sharply during 2001-2017. During this period, real estate prices (see Fig. 2) also increased by $20 \%$ per year. Unemployment remained unchanged at $4.7 \%$. Subsequently, in 2007-2008, all of these indicators worsened catastrophically. GDP has fallen. Real estate prices rose by 10 percent or more. Unemployment has exceeded $10 \%$ across the country.

It is difficult to explain why this happened. Many governments have changed the rules and regulations. Banking legislation in the United States and Europe, for example, has simplified rules that have prevented commercial banks from moving into new business, particularly investment banking. A giant, multinational, "financial supermarket" like Citibank has emerged. Fewer regulatory actions have resulted in more and more 
companies' deep debts. The owners of the apartments bought the houses for very little money. Banks have freely lent finance to tenants to build more homes.

For nearly 20 years, American consumers have paid far more than they received. Lending has stopped. Many firms, companies, corporations and consumers have stopped buying. The economy has "sunk".

After all, this does not mean that there is no problem economy. On the one hand, the Great Recession of 2007-2009 has clearly attracted widespread attention. After the economic downturn, many companies refrained from investing in factories and buying equipment.

The financial crisis has made banks very cautious in issuing new loans. Starting a new business became very complicated.

After the world experienced 2007-2009, it is highly unlikely that deregulation, leveraging, investment banking and globalization, which had driven economic growth over the past 50 years, would again be a factor in growth.

\subsection{Workforce trends:}

The situation is compounded by the fact that the world workforce is growing more slowly than expected. This is bad because if employers do not have enough workers, they will not be able to expand. While this increase was $0.7 \%$ in the 2002-2012 decade (Ready D., Hill L, and Thomas R, 2014)? Why has the workforce slowed? Mostly because of the generation born after World War II. They became older. This period belongs to the period of demographic explosion. The current share of labour force participation in the current generation is declining. In other words, the percentage of the population that wants to work declines sharply. We must conclude, therefore, that economic growth will also slow down.

\section{METHODOLOGY}

We have studied the experience that exists for effective and innovative use of freelancers, social networks and internet applications. We brought them in contact with a number of macroeconomic agents and set out directions and outlines for further research.

\section{RESULTS}

In close collaboration with line managers, HR managers have been helping employers find, hire, dismiss, administer, evaluate employees. Nevertheless, there are trends in personnel management that substantially change perceptions of how well employers are coping with their It should be noted that the HR department's style and methods are constantly changing. Because of this, many employers are re-examining the organization 
of their HR functions.HR tasks. Many plan to deploy technologies to implement a large number of shared services or transactional agreements.

They create a centralized staffing division, which is staffed across all departments of the company to assist line managers in personnel management. These types of HR Centers operate through intranets (centralized networks) or centralized call centers;

They are intended to provide managers and employees with specialized assistance in the day-to-day management of personnel. It is also possible to have corporate HR teams in the company. This helps senior management resolve important issues related to the development of staffing aspects of the company's longterm strategic plan.

\section{DISCUSSION}

"Talent management" is, recruiting, developing, retaining and resolving the company's workforce and it is main challenge.

An unbalanced workforce is another economic innovation. This is partly due to the fact that fewer and fewer people are looking for work. In addition, demand for the workforce is unbalanced. For example, the "average" unemployment rate, say $5 \%$, is masked by the fact that the unemployment rate among college graduates is much higher. And the unemployment rate among software professionals is much lower.

Nearly half of US college graduates are employed in jobs requiring less than four years of college education. (Vedder R., Christopher Denhart Ch., and Robe J. 2019)

Why did this happen? Because most jobs created in the economy over the last few years do not require college education, and as the Bureau of Labor Statistics says (Bureau of Labor Statistics, "Economic Projections: 2012-2022 Summary), this is likely to continue. About two-thirds of workers have been engaged in recent years with activities that do not typically require further schooling. (Ferris, 2022), typically do not require further college education to get a job. This will result in an unbalanced workforce in some professions. For example, unemployment in the high technology sector is low (Ferris, 2022), while in others it is very high (Ferris, 2022). Recruiters in some companies do not find suitable candidates, while in others there is a fall in candidates.

Today, the fact is that most workers are employed in services that are far below their competences. This explains why $70 \%$ of respondents said they were psychologically alienated from their jobs. In any case, the slowdown in the economy and the imbalance in the workforce mean that employers have to work hard to achieve the best results from their employees.

Chapter 3. Technological Trends. It is possible that technologies have identified the most up-to-date human resource management trends. For example, consulting firm Accenture (Accenture, "Top Trends That Will 
Reshape the Future of HR.") estimates that social media outlets such as LinkedIn make up to $80 \%$ of new recruits in a short time, and this is done by line managers bypassing the HR department.

Several basic types of digital technologies provide the transfer of functions from HR personnel to computers. Employers are increasingly using social media tools such as Twitter, Facebook, and LinkedIn. They also use new mobile applications, such as monitoring employee location and providing digital photos.

Websites such as Knack (https://www.knack.com/), True Office (https://www.trueofficelearning.com/) allow the employer to incorporate game features in training, performance, evaluation and recruitment.

Cloud computing and more intuitive user interfaces allow employers to monitor and report on how team goals are being implemented. It displays evaluation feedback in real time. Finally, data analytics mainly involves statistical methods, algorithms, data interrelationships, and problem solving. Talent analytics fundamentally changes how an employer looks for a new employee.

Retrospective talent analytics research shows that the following is significant: how grammatically correct their resumes were; that they did not drop out of school until earning a degree; they were successful at their previous jobs. Technological changes also affect the nature of jobs. When you talk about "tech work," everyone can imagine work at Apple and Google. But technologies apply to all kinds of work.

About 17 million people (Bloomberg BNA Bulletin to Human Resources Management, (2017), use information technology from a remote place to work at least once a month. Co-working sites offer freelancers access to office space, Wi-Fi, and office equipment.

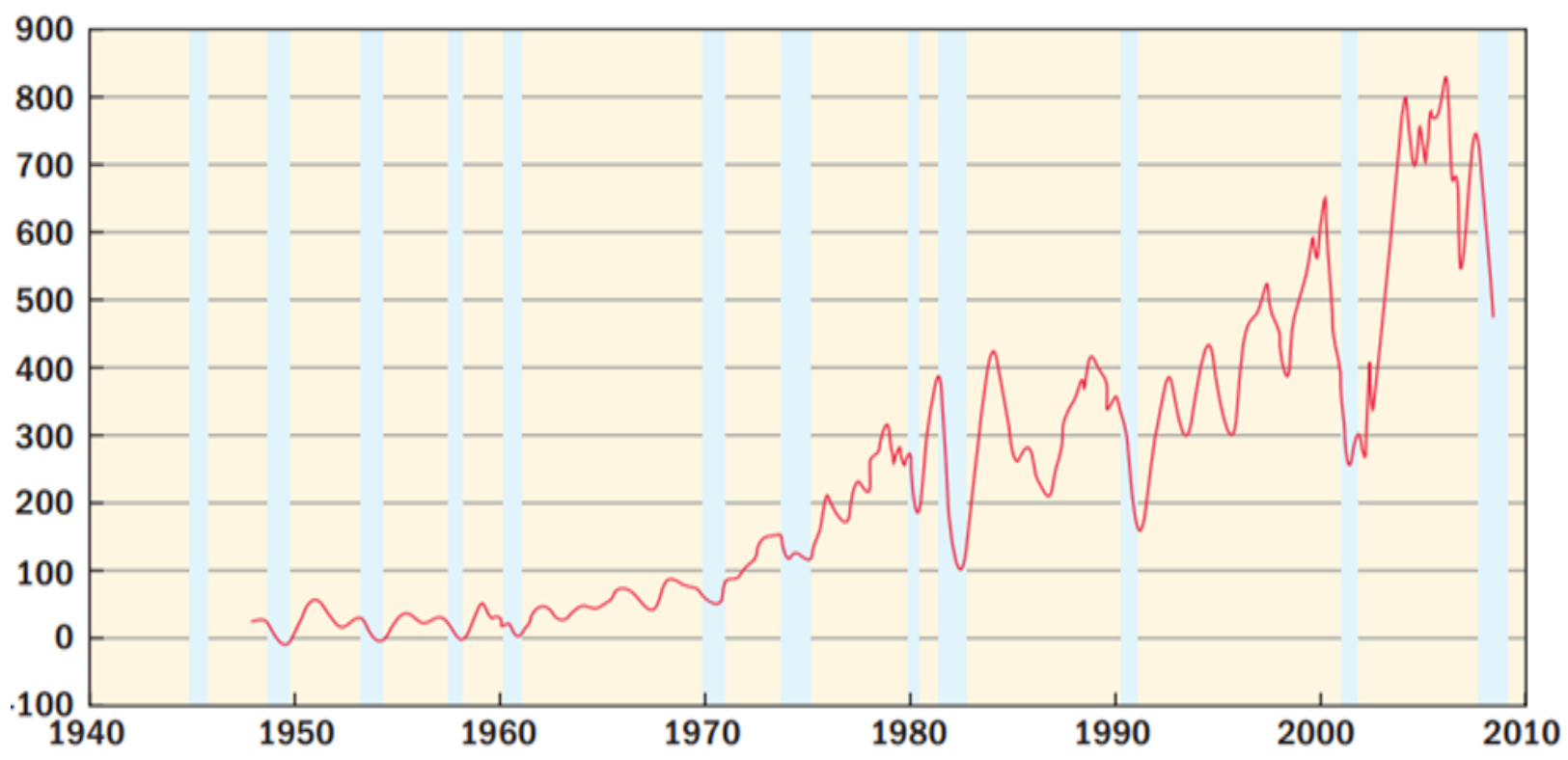

Figure 1. US Gross Domestic Product, 1940-2010

Source: Bureau of Economic Analysis U.S. Department of Commerce, 2020 


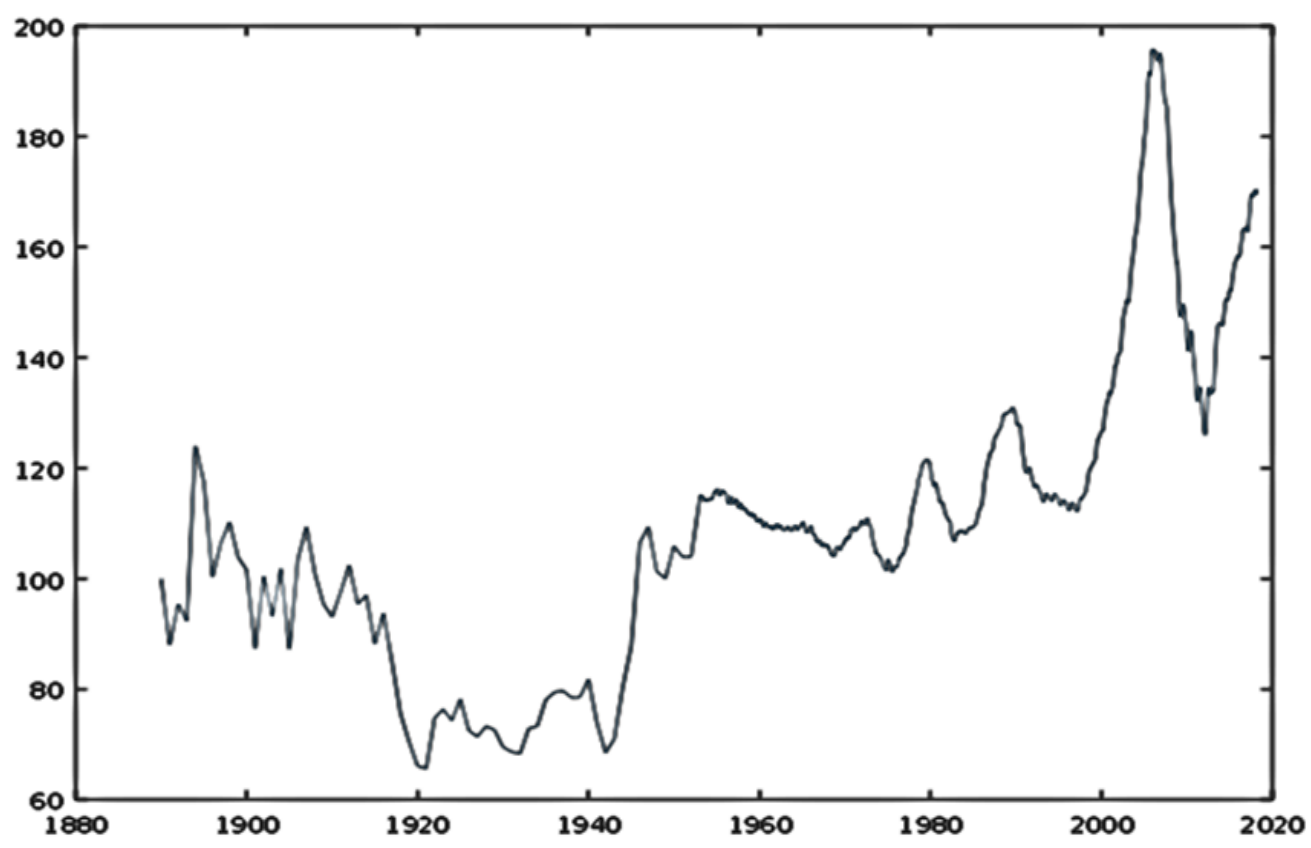

Figure 2. Key-Schiller Real Estate Price Index 1880-2020

Source: Federal Reserve Bank, 2020

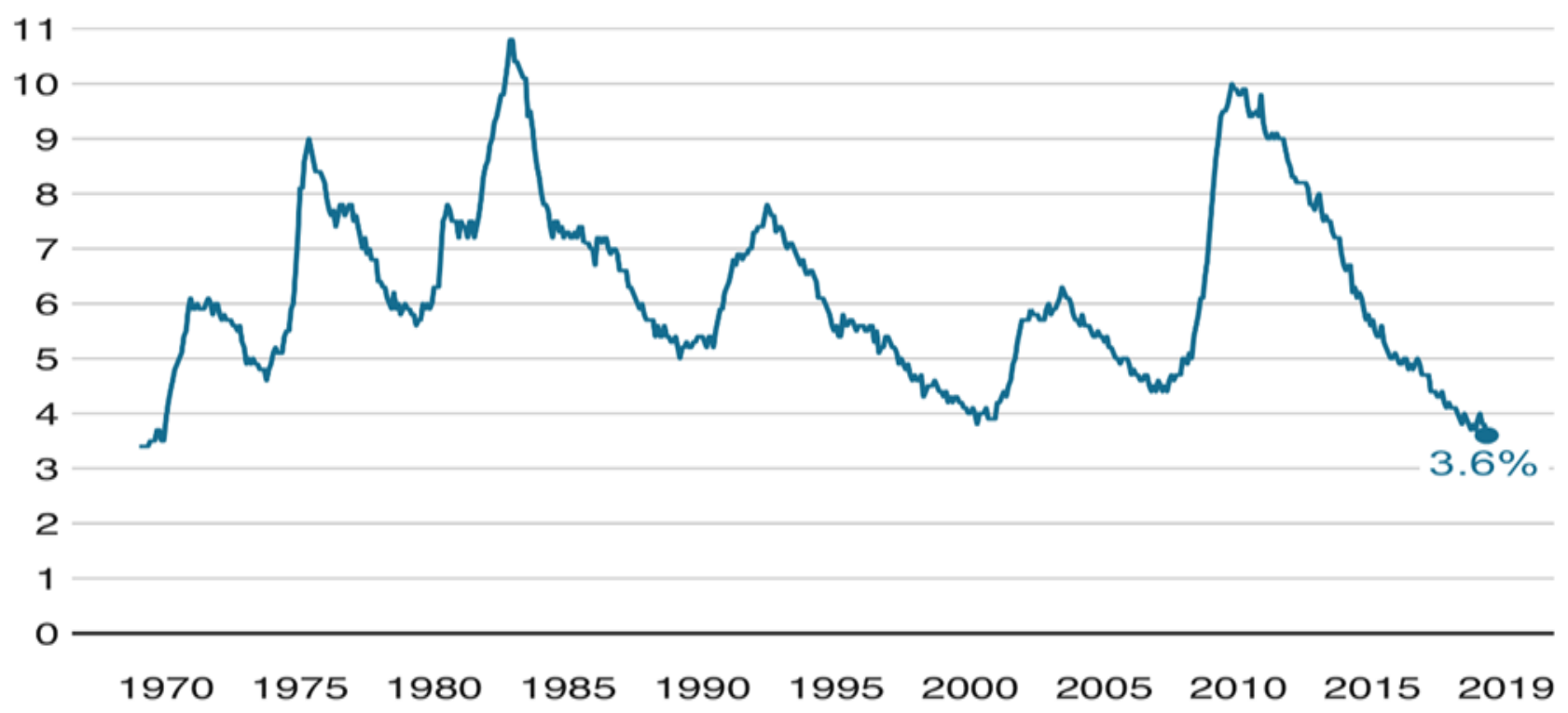

Figure 3. US Unemployment Rate for 1970-2019

Source: U.S. Bureau of Labor Statistics, 2020 


\section{CONCLUSION}

In close collaboration with line managers, HR managers have been helping employers find, hire, dismiss, administer, and evaluate employees. Nevertheless, there are trends in personnel management that substantially change perceptions of how well employers are coping with their It should be noted that the HR department's style and methods are constantly changing. Because of this, many employers are re-examining the organization of their HR functions. HR tasks. Many plan to deploy technologies to implement a large number of shared services or transactional agreements.

They create a centralized staffing division, which is staffed across all departments of the company to assist line managers in personnel management. These types of HR Centers operate through intranets (centralized networks) or centralized call centers;

They are intended to provide managers and employees with specialized assistance in the day-to-day management of personnel. It is also possible to have corporate HR teams in the company. This helps senior management resolve important issues related to the development of staffing aspects of the company's longterm strategic plan.

\section{Conflict of interests}

The authors declare no conflict of interest.

\section{References}

Bureau of Labor Statistics, (2013), "Employment Projections: 2012-2022 Summary," December 19, 2013 https://www.bls.gov/opub/mlr/2020/beyond-bls/retirement-expectations-whether-to-retire-now-or-later.htm (accessed: May, 2020).

Bloomberg BNA Bulletin to Human Resources Management (2017). https://www.bna.com/uploadedFiles/BNA_V2/ HR/Products/Subscriptions/HR Administration/097913\%2023573\%20HR\%20BRO\%20HR\%20Payroll\%20Catalog\%20BRAVO.PDF (accessed: May 2020)

Coy P. (2014). This Economist Foresees 15 Years of Labour Shortages. Bloomberg Business Week, https://www.bloomberg.com/news/articles/2014-03-21/this-economist-foresees-15-years-of-labor-shortages, (accessed: April 2020).

Douglas R., Linda Hill, and Robert Thomas. (2014). "Building a Game-Changing Talent Strategy,” Harvard Business review, January-February 2014, pp. 63-68.

Ferris, D. (2012). "X-factor for Factories Is Factoring-In Recruiting," Workforce Management, December 2012, p. 8

"Here, There and Everywhere" (2013). The Economist, https://www.economist.com/sites/default/files/ 20130119 offshoring davos.pdf. (accessed: May 2020)

Miller R, (2014) "Yellen Fed Resigns Itself to Diminished Growth Expectations,", https://www.bloomberg. com/news/articles/2014-05-02/yellen-s-fed-resigned-to-diminished-growth-expectations, (accessed: April 2020)

Ready D, Hill, L. and Thomas R. (2014). "Building a Game-Changing Talent Strategy" Harvard Business review, https://hbr.org/2014/01/building-a-game-changing-talent-strategy. (accessed: 20 April 2020)

Thibodaux P. (2012), "Offshoring Shrinks Number of IT Jobs, Study Says" https://www.computerworld. com/article/2502949/offshoring-shrinks-number-of-it-jobs--study-says.html (accessed: 15 April 2020)

Vedder, Richard; Denhart, Christopher; Robe, Jonathan. (2013). Why Are Recent College Graduates Underemployed? University Enrollments and Labor-Market Realities. The Center for College Affordability and Productivity (NJ1), https://files.eric.ed.gov/fulltext/ED539373.pdf (accessed April 30, 2020) 


\begin{abstract}
About the authors

\section{Zurab MUSHKUDIANI.}

Professor Mushkudiani is a leading researcher at Batumi Navigation Teaching University. He received his PhD from Akaki Tsereteli State University in 2015 and has worked on plenty of local and international educational projects. Also, he worked in Kutaisi City Hall as a PR senior specialist and maintained relationship with public. His specialties are Management, Finance and Education.
\end{abstract}

ORCID ID: $\underline{\text { https://orcid.org/0000-0003-0987-3564 }}$

\title{
Badri GECHBAIA
}

Doctor of Economics, Professor of Batumi Shota Rustaveli State University, Head of the Department of Business Administration, Management and Marketing. Director of the National Institute for Economic Research (Georgia). Doctor of Honoris Causa Chernihiv National University of Technology (Ukraine); Corresponding Member of the Regional Academy of Management (Kazakhstan). Research interests: Strategic Personnel Management; Regional Economic Development Issues

ORCID ID: $\underline{\text { https://orcid.org/0000-0003-2815-2228 }}$

\section{Iza GIGAURI}

Professor at St. Andrew Georgian University (Tbilisi, Georgia), PhD in Business Administration from Ivane Javakhishvili Tbilisi State University (Georgia), MBA from Business School Netherlands (The Netherlands), MBA from American University for Humanities Tbilisi Campus (Georgia), graduated from Ruhr-University Bochum (Germany) and Ilia State University (Tbilisi, Georgia). Alumna of DAAD, NFP Nuffic, and Erasmus Mundus Scholarships. Current research interests include Corporate Social Responsibility (CSR), Social Entrepreneurship, Marketing Strategy, HR Management. ORCID ID: $\underline{\text { https://orcid.org/0000-0001-6394-6416 }}$

\section{Ekaterine GULUA}

PhD in Economics. Professor at Ivane Javakhishvili Tbilisi State University (TSU); Founder and CEO of Human Potential Management Laboratory, Faculty of Economics and Business, TSU: Her current research interests include Management, The Art of Management, Strategic Human Resource Management, Leadership, Talent Management, Human Potential Management, Management of Higher Education Institutions, Management of Organizational Culture, Structuring of Organizations.

ORCID ID: $\underline{\text { https://orcid.org/0000-0001-9484-093X }}$ 